УДК 332.812 .12

\section{В.П. Прокопович}

ФГБОУ ВПО «МГСУ»

\section{РЕШЕНИЕ ПРОБЛЕМЫ ПЕРЕСЕЛЕНИЯ ГРАЖДАН ИЗ АВАРИЙНОГО И ВЕТХОГО ЖИЛИЩНОГО ФОНДА}

Темпы жилищного строительства не решают проблемы переселения граждан из аварийных и ветхих домов, число которых превышает предельно допустимые значения. Для оценки динамики состояния жилищного фонда использована модель, описывающая путь, пройденный ускоренно движущимся телом. Графическим аналогом модели служит спиралевидная пружина с переменным, возрастающим шагом, из которого следует, что объем аварийного и ветхого жилищного фонда нарастает по экспоненциальному закону. Предложенная модель позволяет прогнозировать возможные последствия от существующих низких темпов переселения граждан; планировать требуемые ежегодные объемы нового строительства для переселения граждан; а также оценивать требуемые дополнительные ресурсы для предотвращения аварийных ситуаций.

Ключевые слова: жилищный фонд, аварийность, математическая модель, графическая модель, прогнозирование, экспоненциальный закон, оптимизация.

Исходными данными для понимания остроты проблемы переселения граждан из аварийного и ветхого жилищного фонда могут служить усредненные нами данные за последние 10 лет, которые свидетельствуют, что в большинстве регионов России, число аварийных и ветхих домов превышает предельно допустимые значения.

Зная о состоянии жилищного фонда, Президент России В.В. Путин отметил: «Сегодня хотел бы несколько слов сказать о расселении жилья, непригодного для проживания... Напомню, что по указам, расселению подлежит так называемый аварийный фонд, признанный таковым на 1 января 2012 года... Что на самом деле получается? Ситуация в этой сфере пока самая плохая. План переселения граждан из аварийного и ветхого жилья в 2013 году выполнен лишь на 4 процента, переселены чуть более 1,5 тысячи человек из запланированных 42 тысяч. Уважаемые коллеги, это просто недопустимо» ${ }^{1}[1-3]$.
V.P. Prokopovich

Moscow State University of Civil Engineering

\section{SOLVING THE PROBLEM OF RELOCATION OF RESIDENTS FROM OLD AND UNFIT HOUSING STOCK}

The speed of construction does not solve the problem of relocating the residents from old and unfit housing stock, the number of which exceeds the maximum permissible values. To assess housing stock condition, the author uses a model describing the path traversed by an accelerated body. The graphic analogue of model is a coil spring with a variable, increasing step, from which it follows that the volume of old and unfit housing stock is growing exponentially. The proposed model helps to project possible consequences of slow relocation, to plan necessary annual volume of new construction for relocation of the residents, as well as to assess the additional resources for preventing accidents.

Key words: housing stock, accidence, mathematical model, graphic model, forecasting, exponential law, optimization.

The average data of the last 10 years help to understand the problem of relocation of people from old and unfit housing stock. This data shows that the number of old and unfit houses exceeds threshold values.

Considering the state of housing stock V.V. Putin declared: "Today I'd like to say a few words about the relocation from unfit houses...I'd like to remind, that, according to the decree, relocation relates to the houses recognized as unfit since the 1st of January 2012. But what happens in fact? The situation in this sphere is the worst. In 2013 we fulfilled the plan of relocation for only 4 per cent. That means a bit more than 1.5 thousand instead of 42 thousand, according to the plan. Dear colleagues, that's simply impermissible" $[1-3]$.

\footnotetext{
${ }^{1}$ Стенографический отчет о совместном заседании Государственного совета и Комиссии при Президенте по мониторингу достижения целевых показателей социально-экономического развития России. Режим доступа: http://www.kremlin.ru/news/19882. Дата обращения: 23.12.2013.

Stenograficheskiy otchet o sovmestnom zasedanii Gosudarstvennogo soveta i Komissii pri Prezidente po monitoringu dostizheniya tselevykh pokazateley sotsial'no-ekonomicheskogo razvitiya Rossii [Verbatim Report of Joint Meeting of State Council and Presidential Commission on Monitoring of Social Indicator in Russia]. Available at: http://www.kremlin.ru/news/19882. Date of access: 23.12.2013.
} 
И как показал проведенный нами анализ, данная «ситуация» усугубляется тем, что объем аварийного и ветхого жилищного фонда нарастает по экспоненциальному закону [4, 5], и приближается к критическому состоянию.

При этом нам представляется, что вопрос не только в неэффективном использовании бюджетных средств, но и в том, что научно-обоснованные методы и инновационные технологии не используются в процессе нового строительства и капитального ремонта жилищного фонда.

Эффективное решение данной проблемы невозможно без активного участия ученых, инновационных предприятий, инвесторов, строительного и жилищно-коммунального бизнеса.

Ведь темпы нарастания объемов аварийного и ветхого жилья в 2,5...3 раза превышают темпы строительства нового, а качество эксплуатации домов в ряде случаев снижает предельно допустимые межремонтные сроки. В аналогичном критическом состоянии находятся все инженерные системы и трубопроводные сети отопления, водоснабжения и водоотведения. Поэтому проблема переселения граждан из аварийного и ветхого жилищного фонда в последующем будет лишь усугубляться [6].

Предельно допустимые сроки для переселения граждан составляют не более 6-7 лет, а объем требуемого финансирования программы переселения и проведения капитального ремонта жилищного фонда - около 9 трлн р., которых нет ни у государства, ни у населения. В связи с этим становится очевидным, что проблема переселения граждан требует постановки и решения задачи оптимизации всех видов ресурсов для повышения темпов нового строительства, снижения себестоимости и повышения эффективности организации его эксплуатации.

С этой целью нами предложена математическая модель динамики протекания жизненного цикла жилищного фонда (от строительства до перехода в аварийное состояние и утилизации), которая с достаточной степенью достоверности может быть описана общей математической формулой пути $[7,8] S_{t}$ за период времени $t$ при ускоренном движении тела, с начальной скоростью $V_{0}$ и ускорением $a$ :

$$
S_{t}=S_{0}+V_{0} t+\frac{a t^{2}}{2}
$$

где $S_{0}$ - отрезок пути, пройденный к началу измерения пути.
Our analysis showed that the situation aggravates, because the volume of old and unfit housing stock is growing exponentially $[4,5]$ and is close to its critical condition.

It's obvious, that the problem is not only inefficient use of budget but the lack of scientifically based methods and innovative technologies in new construction and major repairs of housing stock.

It' impossible to solve the problem effectively without the help of scientists, innovative companies, investors, construction and housing and public utilities business.

In fact, the growth rate of old and unfit housing stock is $2.5 \ldots 3$ times more than the growth rate of new construction, and the quality of house usage in many cases decreases the limits of period between repairs. All the engineering systems, heating network, water supply and water discharge systems are in the same critical condition. That's why the situation with the relocation will get worse.

The limit terms of relocation of residents are not more than $6-7$ years and the amount of financing of relocation program is about 9 billion rubles. Neither the State nor people have this money. So it' obvious, that the problem of relocation of residents demands optimization of all the resources for increasing the growth rate of construction, reduction of costs and increasing the effectiveness of its exploitation.

For that purpose we offer mathematical model of housing stock life cycle (from construction till unfit condition and utilization). This module can be described with the general mathematical formula of path progression $[7,8] S_{t}$ for the period of time $t$ with accelerated body motion, with a given speed $V_{0}$ and acceleration $a$ :

where $S_{0}$ - a sub path, traversed before measuring. 
В данной модели изначально пройденный путь соответствует общему количеству жилищного фонда на момент времени $t_{0}$; путь, пройденный за время $t$ со скоростью $V_{0}$, соответствует общему количеству жилищного фонда на период времени $t$; путь, пройденный за время $t$ с ускорением - соответствует приращению количества жилищного фонда за время $t$.

Исходя из (1), общее состояние жилищного фонда может быть описано следующей математической моделью:
The path, in the given model, corresponds to the total amount of housing stock at a given time $t_{0}$; path, traversed in a time $t$ with a speed $V_{0}$ corresponds to the total amount of housing stock for the period of time $t$;

Path, traversed in a time $t$, with acceleration - corresponds to the excess amount of housing stock in a time $t$.

On account of (1), general state of the housing stock can be described with the following model:

$$
G_{t}=G_{0}+\left[\frac{\Delta G_{0}^{\mathrm{H}}}{\Delta t}+\frac{\Delta \Delta G_{t}^{\mathrm{H}}}{2 \Delta \Delta t} t\right] t-\left[G_{0}^{\mathrm{a}}+\frac{\Delta G_{0}^{\mathrm{B}}}{\Delta t}+\frac{\Delta \Delta G_{0}^{\mathrm{B}}}{2 \Delta \Delta t}\right] t,
$$

где $G_{t}$ - общее количество жилищного фонда на момент времени $t ; G_{0}$ - общее количество жилищного фонда, на данный момент времени $t_{0} ; \frac{G_{0}^{\text {н }}}{\Delta t}-$ темпы строительства жилищного фонда за последний год, до начала моделирования, аналог 1-й производной нового строительства (н) за прошедший год; $\frac{\Delta \Delta G_{t}^{\mathrm{H}}}{2 \Delta \Delta t} t$ ежегодное приращение темпов строительства жилищного фонда, аналог 2-й производной от (н) по времени; $G_{0}^{\mathrm{a}}-$ количество аварийного жилищного фонда, подлежащего сносу (a) на момент времени $t_{0} ; \frac{\Delta G_{0}^{\text {в }}}{\Delta t}-$ темпы сокращения жилищного фонда за прошедший год, в связи с переходом ветхого жилья (в) в аварийное состояние, аналог 1-й производной количества аварийного жилищного фонда по времени; $\frac{\Delta \Delta G_{0}^{\text {в }}}{2 \Delta \Delta t}-$ ежегодное приращение темпов сокращения жилищного фонда, аналог 2-й производной перехода ветхого жилья в аварийное состояние по времени. Тогда, для обеспечения новым жильем проживающих в аварийном и ветхом жилищном фонде граждан в требуемые сроки $(t)$, необходимо чтобы

$$
G_{0}+\left[\frac{\Delta G_{0}^{\mathrm{H}}}{\Delta t}+\frac{\Delta \Delta G_{t}^{\mathrm{H}}}{2 \Delta \Delta t} t\right] t>\left[G_{0}^{\mathrm{a}}+\frac{\Delta G_{0}^{\mathrm{B}}}{\Delta t}+\frac{\Delta \Delta G_{0}^{\mathrm{B}}}{2 \Delta \Delta t}\right] t,
$$

Лишь в этом случае, $\Delta G_{t}=G_{t}-G_{0}>0$, Only in this case, $\Delta G_{t}=G_{t}-G_{0}>0$, что свидетельствует о возможности переселения граждан во вновь построенные жилые дома за период времени $t$. where $G_{t}$ - total amount of housing in time $t ; G_{0}$ - total amount of housing stock, in a given moment $t_{0} ; \frac{G_{0}^{\mathrm{H}}}{\Delta t}-$ growth rate of construction for the last year, before modeling, analogue of the first derivative of new construction (H) for the last year; $\frac{\Delta \Delta G_{t}^{\mathrm{H}}}{2 \Delta \Delta t} t-$ annual growth rate excess of housing stock construction, analogue of the 2nd derivative from (н) on time; $G_{0}^{\mathrm{a}}$ - the amount of unfit housing stock, due to utilization (a) at a time $t_{0} ; \frac{\Delta G_{0}^{\mathrm{B}}}{\Delta t}$ - reducing growth rate for the last year, because of failure state of old houses, analogue of the derivative of unfit housing stock amount in time; $\frac{\Delta \Delta G_{0}^{\mathrm{B}}}{2 \Delta \Delta t}-$ annual access of reducing growth rate of housing stock, analogue of the 2 nd derivative of failure state of old housing stock in time.

Then, in order to supply the residents of old and unfit housing stock with new homes when required $(t)$, it's necessary to: 
Однако ежегодные темпы роста аварийного жилья в 3 и более раз выше ежегодных темпов нового строительства, $\Delta G_{t}=$ $=G_{t}-G_{0}>0$, поэтому количество аварийного и ветхого жилищного фонда, а следовательно и аварий растет по экспоненциальному закону.

Это наглядно отображено на графической модели в виде спиралевидной пружины с переменным (возрастающим) шагом (рис.).
However, the annual growth rate of unfit housing stock is 3 or more times higher than the annual growth rate of new construction. $\Delta G_{t}=G_{t}-G_{0}<0$, So, the total amount of old and unfit housing stock is growing exponentially.

That is clearly shown at a graphic model of spiral spring with a variable, increasing step (fig.).

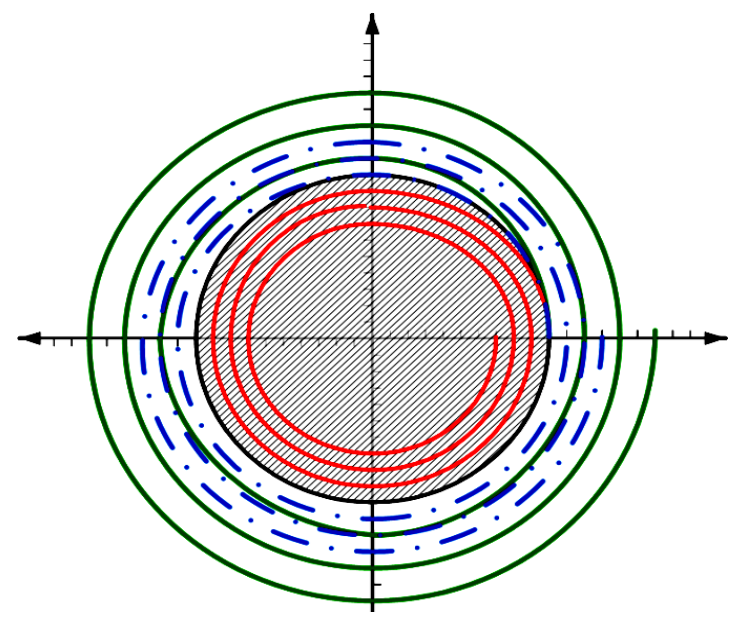

Графическая модель динамики изменения состояния жилищного фонда

Из предложенной математической модели и ее графической интерпретации видно, что при существующих темпах строительства и организации капитального ремонта динамика нарастания аварийности носит лавинообразный характер, что угрожает здоровью и самой жизни граждан. А накопленный «недоремонт» по нашим расчетам к 2030 г. составит более $50 \%$.

Математическая модель позволяет научно обосновать необходимые ежегодные темпы нового строительства, которые обеспечат переселение граждан как из аварийного жилищного фонда, так и из ветхого жилищного фонда, перешедшего в аварийное состояние, а также определить объем накопленного ветхого жилья, с учетом перехода в это состояние жилищного фонда, находившегося на стадии эксплуатации.

Задача ученых заключается в том чтобы, вместо недостающих финансовых ресурсов, изыскать оптимальные организационноуправленческие, научно-технологические, инженерно-конструкторские и другие нематериальные ресурсы для повышения темпов ежегодного строительства нового жилья и каcondition

Graphic model of time history of housing stock

The offered mathematical model and its graphic interpretation shows, that, considering the present growth rate of construction and major repairs management, accident risk is snowballing, that threatens people's health and life. And the volume of total "underrepairs" will have amounted to $50 \%$ by 2030 .

Mathematical model scientifically proves the necessary annual growth rate of construction that will help to relocate people not only from risky houses but from old and unfit houses as well.

And to define the volume of accumulated old housing stock, considering the stock during service.

Scientists face the problem of finding optimal managing, scientific and technological, engineering and design and other nonmaterial resources, instead of financial resources, to increase the growth rate of annual new construction and major repairs to the demanded level of social tariffs.

Optimization of all the resources demands solving of combination of sheer scientific tasks: calculating the growth rate of utilization (reconstruction) of accident and old hous- 
питального ремонта жилищного фонда до требуемого уровня по социально-приемлемым тарифам.

Оптимизация всех видов ресурсов требует решения совокупности частных научных задач: расчета требуемых темпов сноса (реконструкции) аварийного и ветхого жилищного фонда по категориям зданий; темпов ежегодного строительства для замещения выбывающего аварийного и ветхого жилищного фонда с учетом предоставления жилья молодым семьям.

Аналогичные частные задачи оптимизации требуемых темпов сноса (реконструкции) аварийного и ветхого жилищного фонда, а также темпов ежегодного нового строительства необходимо решать по каждому региону России с учетом их особенностей и имеющихся нематериальных и материальных ресурсов.

При этом частными научными задачами оптимизации являются задачи, учитывающие особенности каждого региона: ектов;

выбор оптимальных архитектурных про-

оптимальных инженерно-конструкторских решений и энергосберегающих стройматериалов;

энергоэффективных трубопроводных систем тепло-, водоснабжения и энергообеспечения;

современных систем утилизации бытовых отходов и обеспечения экологической безопасности территорий;

систем экономного потребления воды, тепла, энергоресурсов;

альтернативных источников энергии;

разработки и внедрения инновационных материалов и перспективных архитектурноконструкторских решений для стройиндустрии будущего.

Целенаправленное управление научными исследованиями ППС, докторантов, аспирантов и студентов вузов с целью решения названных задач позволит решить государственную, социально-значимую проблему переселения граждан из ветхого и аварийного жилищного фонда в установленные сроки при ограниченных ресурсах.

\section{БИБЛИОГРАФИЧЕСКИЙ СПИСОК}

1. Постановление Правительства Российской Федерации от 22 января 2002 г. № 33 «О подпрограмме «Переселение граждан Российской Федерации из ветхого и аварийного жилищного фонда», входящей в со- ing stock on different categories of buildings; growth rate of annual construction for changing accident and old housing stock, considering provision of housing to young families.

The same specific tasks of reconsideration of present growth rate of utilization (reconstruction) of failing and old housing stock and the growth rate of new construction should be regarded in each region of Russia, regarding the special conditions and material and non material resources.

The specific tasks of optimization are those which consider special features of each region:

choosing optimal design projects;

optimal engineering solutions and power saving construction materials;

energy effective pipe systems of heat, water and energy supply;

modern systems of domestic waste recovery and environmental security supply;

systems of economic use of water, heat and energy resources;

alternative energy resources;

development and application of innovative materials and design solutions for construction industry of the future.

Basing on the above-mentioned material it's possible to manage purposefully the scientific researches of higher-education teaching personnel, doctorates, postgraduates, which in due time helps to solve the most important problem of relocation of residents from old and unfit housing stock at a stated time under limited resources.

\section{REFERENCES}

1. Postanovlenie Pravitel'stva Rossiyskoy Federatsii ot 22 yanvarya 2002 g. № 33 «O podprogramme "Pereselenie grazhdan Rossiyskoy Federatsii iz vetkhogo $i$ avariynogo zhilishchnogo fonda», vkhodyashchey $v$ sostav federal'noy tselevoy programmy "Zhilishche» na 2002-2010 gody2010 gody» [Governmental Decree of Russian Federation from 22.01.2002 № 33 “On the Program of "Relocation of Russian Residents from Old and Failing Housing Stock" Included in Federal Social Program "Home" for 2002-2010"] Available at: http://www.moskv.ru/laws /fulltext/ show/id/2414. Date of access: 10.02.14.

2. Postanovlenie Pravitel'stva Rossiyskoy Federatsii ot 17 dekabrya 2010 g. № 1050 «O federal'noy "Home" for 2011-2015»] Available at: tselevoy programme "Zhilishche» na 2011-2015 gody». [Govern mental Decree of Russian Federation from 17.12.2010 № 1050 “On Federal Social Program http://www.fcpdom.ru/index.php?option=com_content 
став федеральной целевой программы «Жилище» на 2002-2010 годы». Режим доступа: http://www.moskv. ru/laws/ fulltext/show/id/2414. Дата обращения: 10.02.2014

2. Постановление Правительства Российской Федерации от 17 декабря 2010 г. № 1050 «О федеральной целевой программе «Жилище» на 2011-2015 годы». Режим доступа: http://www.fcpdom.ru/index.php? option=com_content $\&$ view=article $\& i d=141$ :postanovleniepravitelstva-rossijskoj-federatsii-ot-17-dekabrya-2010-g1050-o-federalnoj-tselevoj-programme-zhilishche-na-20112015-gody\&catid=22\&Itemid=274. Дата обращения: 10.02.2014.

3. Ветхий и аварийный жилищный фонд // Социальное положение и уровень жизни населения России 2013 г. / Федеральная служба государственной статистики. Режим доступа: http://www.gks.ru/bgd/regl/ b13_44/Main.htm. Дата обращения: 21.02.2014.

4. Моисеев Н.Н. Математические задачи системного анализа. М. : Наука, 1981. 488 с.

5. Белавин В.А., Капииа С.П., Курдюмов С.П. Математическая модель глобальных демографических процессов с учетом пространственного распределения // Журнал вычислительной математики и математической физики. 1998. № 6. С. 885-902.

6. Шкред К.В. Улучшение жилищных условий как важнейшее условие повышения качества жизни населения // Аналитический вестник Совета Федерации ФС РФ. 2010. № 10 (396). С 31-34.

7. Карпелевич Ф.И., Садовский Л.Е. Элементы линейной алгебры и линейного программирования. М. : Наука, 1967. 312 с.

8. Боярский А.Я. Теоретические исследования по

Поступила в редакиию в марте 2014 г. статистике. М. : Статистика, 1974. 305 с.

\&view=article \&id=141:postanovlenie-pravitelstvarossijskoj-federatsii-ot-17-dekabrya-2010-g-1050-ofederalnoj-tselevoj-programme-zhilishche-na-20112015-gody\&catid=22\&Itemid=274. Date of Access: 10.02.14.

3. Vetkhiy i avariynyy zhilishchnyy fond [Old and Unfit Housing Stock]. Sotsial'noe polozhenie i uroven' zhizni naseleniya Rossii - 2013 [Social Status and Living Standards of Russian Population- 2013.] / Federal'naya sluzhba gosudarstvennoy statistiki [Federal State Statistics Service]. Available at: http://www.gks.ru/bgd/regl/b13_44/Main.htm. Date of access: 21.02.14.

4. Moiseev N.N. Matematicheskie zadachi sistemnogo analiza [Mathematical Problems of System Analysis]. Moscow, Nauka Publ., 1974, 312 p.

5 Belavin V.A., Kapitsa S.P., Kurdyumov S.P. Matematicheskaya model' global'nykh demograficheskikh protsessov s uchetom prostranstvennogo raspredeleniya [Mathematical Model of Global Population Process with Account of Space Distribution]. Zhurnal vychislitel'noy matematiki $i$ matematicheskoy fiziki [Journal of Numerical Mathematics and Mathematical Physics]. 1998, no. 6, pp. 885-902.

6. Shkred K.V. Uluchshenie zhilishchnykh usloviy kak vazhneyshee uslovie povysheniya kachestva zhizni naseleniya [Improving Housing Conditions as the Most Important Factor of Improving Living Standards of Population ]. Analiticheskiy vestnik Soveta Federatsii FS [Analytic Messenger of Federation Council of Russian Federal Service]. 2010, no. 10 (396), pp. $31-34$.

7. Karpelevich F.I., Sadovskiy L.E. Elementy lineynoy algebry i lineynogo programmirovaniya [Elements of Linear Algebra and Lineal Programming]. Moscow, Nauka Publ., 1967, 312 p.

8. Boyarskiy A.Ya. Teoreticheskie issledovaniya po statistike [Theoretical Statistical Researches]. Moscow: Statistika Publ., 1974, 312 p.

Received in March 2014

Об авторе: Прокопович Владимир Павлович, кандидат военных наук, доцент, член-корреспондент РАЕН, академик МАИСТ, доцент кафедры государственного и муниципального управления, Московский государственный строительный университет (ФГБОУ ВПО «МГСУ»), 129337, г. Москва, Ярославское шоссе, д. 26, 8 (495) 678-30-16, sbgvp@mail.ru.
About the author: Prokopovich Vladimir Pavlovich, Candidate of Military Sciences, Associate Professor, Corresponding Member of Russian Academy of Natural Sciences, Academician of Academy of Social Sciences and Local Self Management, Department of State and Municipal management, Moscow State University of Civil Engineering (MGSU), 26 Yaroslavskoe shosse, Moscow, 129337, Russian Federation; +7 (495) 678-30-16, sbgvp@ mail.ru.

\section{Для цитирования:}

Прокопович В.П. Решение проблемы переселения граждан из аварийного и ветхого жилищного фонда [Электронный pecypc] // Строительство: наука и образование. 2014. Вып. 2. Ст. 3. Режим доступа: http://www.nso-journal.ru.

For citation:

Prokopovich V.P. Reshenie problemy pereseleniya grazhdan iz avariynogo i vetkhogo zhilishchnogo fonda [Solving the Problem of Relocation of Residents from Old and Unfit Housing Stock]. Stroitel'stvo: nauka i obrazovanie [Construction: Science and Education]. 2014, no. 2, paper 3. Available at: http://www.nso-journal.ru. 